\title{
Effect of Cultivars and Planting Date on Yield, Oil Content, and Fatty Acid Profile of Flax Varieties (Linum usitatissimum L.)
}

\author{
Maricel Andrea Gallardo, ${ }^{1}$ Héctor José Milisich, ${ }^{1}$ \\ Silvina Rosa Drago, ${ }^{2,3}$ and Rolando José González ${ }^{2}$ \\ ${ }^{1}$ Instituto Nacional de Tecnología Agropecuaria (INTA), Estación Experimental Paraná, Ruta 11, Km. 12.5, \\ Entre Ríos, 3100 Paraná, Argentina \\ ${ }^{2}$ Instituto de Tecnología de Alimentos, Facultad de Ingeniería Química, Universidad Nacional del Litoral, \\ Santiago del Estero 2829, 3000 Santa Fe, Argentina \\ ${ }^{3}$ Consejo Nacional de Investigaciones Científicas y Técnicas (CONICET), Avenida Rivadavia 1917, C1033AAJ Buenos Aires, Argentina
}

Correspondence should be addressed to Maricel Andrea Gallardo; gallardo.maricel@inta.gob.ar

Received 29 May 2014; Revised 20 August 2014; Accepted 28 August 2014; Published 15 September 2014

Academic Editor: Yong In Kuk

Copyright ( 2014 Maricel Andrea Gallardo et al. This is an open access article distributed under the Creative Commons Attribution License, which permits unrestricted use, distribution, and reproduction in any medium, provided the original work is properly cited.

\begin{abstract}
In order to determine the effect of cultivars and planting date on flax fatty acid profile, seed yield, and oil content, an assay with seven cultivars (Baikal, Prointa Lucero, Prointa Ceibal, Panambí INTA, Curundú INTA, Carapé INTA, and Tape INTA) was carried out at Parana Agricultural Experimental Station, Argentina. Significant differences among cultivars were found for content of palmitic (5-7 g/100 g), stearic (5-8 g/100 g), linoleic (13-19 g/100 g), saturated (11-15 g/100 g), and unsaturated acids ( $92-96 \mathrm{~g} / 100 \mathrm{~g})$ within the seven cultivars. The best seed yields were observed in Prointa Lucero and Carapé INTA varieties $\left(2091.50 \mathrm{~kg} \cdot \mathrm{ha}^{-1}\right.$ and $2183.34 \mathrm{~kg} \cdot \mathrm{ha}^{-1}$, respectively) in the first planting date and in Carapé INTA and Prointa Lucero (1667 kg.ha ${ }^{-1}$ and $1886 \mathrm{~kg} \cdot \mathrm{ha}^{-1}$, respectively) in the second planting date. A delayed planting date had a negative effect on seed yield (1950 kg.ha ${ }^{-1} \mathrm{and}_{1516 \mathrm{~kg} \cdot \mathrm{ha}}{ }^{-1}$ ) and oil content $\left(845 \mathrm{~kg} \cdot \mathrm{ha}^{-1}\right.$ and $\left.644 \mathrm{~kg} \cdot \mathrm{ha}^{-1}\right)$ but did not affect oil composition.
\end{abstract}

\section{Introduction}

Flaxseed, derived from the seeds of the flax plant Linum usitatissimum, belongs to the Linaceae family. Flaxseed is one of the most important cultivated plants concerning its linen and oil. This species is planted mostly for oil and textile industry. Fibre flax is mainly grown in some regions of northern Europe, Russia, and China, while oilseed flax is widely grown in cool temperate regions of Argentina, India, China, Russia, USA, and Canada. However, the flax is mostly being harvested for oil so, it is an economically important oilseed crop [1].

Flax industrial quality is attributable to the oil concentration of its seeds, which may vary from 38 to $46 \mathrm{~g} / 100 \mathrm{~g}$ [2], from 30 to $45 \mathrm{~g} / 100 \mathrm{~g}$ [3] and from 36 to $48 \mathrm{~g} / 100 \mathrm{~g}$ [4-6]. It also has a high content of total dietary fiber and proteins.

Flaxseed oil has a very healthy fatty acid (FA) profile, with low levels $(9 \mathrm{~g} / 100 \mathrm{~g})$ of saturated FA, moderate levels
(18 g/100 g) of monounsaturated fatty acids, and high concentrations $(73 \mathrm{~g} / 100 \mathrm{~g})$ of polyunsaturated fatty acids (PUFA). The PUFA content comprises about $16 \mathrm{~g} / 100 \mathrm{~g}$ 18:2n-6 FA (linoleic acid) and $57 \mathrm{~g} / 100 \mathrm{~g}$ 18:3n-3 FA (linolenic acid) [7]. The linolenic acid in particular occurs in a higher level as compared to other products, such as soybean, canola, and corn oils.

Linolenic acid (18:3n-3) and linoleic acid (18:2n-6) are considered to be indispensable for human beings and must be obtained from food oils and fats. They are important nutrients for nervous system and the intake of linolenic acid being particularly helpful for a good blood circulation and a heart protection.

At present, nutritionists consider that the ideal edible oils should contain about $3.0 \mathrm{~g} / 100 \mathrm{~g}$ linolenic acid [8].

The 18:3n-3 FA is essential for normal growth and has biological effects very useful in the prevention and treatment 
of coronary artery disease, hypertension, diabetes, arthritis, other inflammatory and autoimmune disorders, and certain types of cancers $[9,10]$.

The 18:2n-6/18:3n-3 ratio, which is estimated to be around 15-20 in the current Western diet [11], should decrease to below 5 or 4 to avoid the prothrombotic and proaggregatory state induced by a high level of 18:2n-6 PUFA [12].

FA profile makes flax very attractive as a functional food. Therefore, flax addition to the diet would be a healthy option, being particularly attractive from the viewpoint of food development.

It has been suggested that in order to obtain high yields and a good FA profile, plants must be handled in such a way that periods for yield determination coincide with favourable conditions for growth.

Oil synthesis in flax begins almost immediately after flowering and it progresses slowly during the 11 following days. After that time, a rapid accumulation of oil occurs for 10 days, achieving $3 \mathrm{~g} / 100 \mathrm{~g}$ a day and reaching a maximum at day 21 after flowering. Oil formation ceases as soon as chlorophyll has been completely removed, the subsequent variations being practically negligible [13].

Flax is adapted to many environments mainly in temperate climates $[14,15]$. It has been demonstrated that seed yield and seed yield components, plant height, time to reach harvest maturity, oil content, and oil composition and depend mainly on the temperature during plant development [1416]. Other factors such as seed moisture at harvest may also influence the final seed oil content and the oil composition [15].

Experiments carried out in controlled conditions showed that high temperatures $\left(>30^{\circ} \mathrm{C}\right)$ during the ripening phase reduce the number of seeds per capsule and the seed weight and decrease oil yield and quality [17].

Seed production and oil production are known to be conditioned by the optimum planting date and the technological level used. Because of its geographical location, weather conditions, and soil characteristics, Entre Rios province of Argentina can be included within the subregion IIB, where the optimum planting date ranges from late May to late June, when temperatures are more conducive to the growth and development of the crop allowing a proper flowering to maturity period.

The aim of this work was to evaluate the effect of cultivars and planting date on the fatty acid profile and oil content of flax (Linum usitatissimum L.) in order to get information about agronomic conditions useful for flax functional food development.

\section{Materials and Methods}

2.1. Field Study. Baikal, Prointa Lucero, Prointa Ceibal, Panambí INTA, Curundú INTA, Carapé INTA, and Tape INTA were the genotypes under study. They were selected according to their releasing dates and oil content, the least content $(40 \mathrm{~g} / 100 \mathrm{~g})$ and the highest content $(45 \mathrm{~g} / 100 \mathrm{~g})$ being found in Tape INTA and Curundú INTA, respectively.
2.2. Experimental Design. The study was carried out during the campaign 2008 at INTA Paraná Agricultural Experimental Station ( $31^{\circ} 50^{\prime} \mathrm{S}, 60^{\circ} 31^{\prime} \mathrm{W}, 11.5$ m.a.s.l.), Argentina, in an Argiudol aquic soil, series Tezanos Pintos.

Flaxseed was planted, on June 11, 2008 (1st dateoptimum planting date) and July 30 (2nd date-late planting date for this region) using a randomized complete block design with three repetitions, parcels having a surface of $3.42 \mathrm{~m}^{2}$. The crop was carried out without water and nutritional constraints and freely of weeds, insects, and diseases, applying all the necessary preventive and curative measures.

Seed samples were taken from each parcel at harvest time (November and December 2008).

\subsection{Methods of Analysis}

2.3.1. Seed and Oil Yield. Seed yield was estimated at harvest time and expressed as $\mathrm{kg} \cdot \mathrm{ha}^{-1}$ (d.b.). Oil content was measured by Nuclear Magnetic Resonance (NMR) Analyzer (Newport 4000, Oxford Institute Limited, Oxford, England) by Robertson and Morrison [18] and expressed as $\mathrm{kg} \cdot \mathrm{ha}^{-1}$ (d.b.).

2.3.2. Fatty Acid Oil Profile. FA content was determined according to Bannon et al. method [19] with modifications.

A sample of 10 ground flaxseed was added with $0.5 \mathrm{~mL}$ of $\mathrm{NaOMe}$ and stirred for 2 minutes. After that, $2.0 \mathrm{~mL}$ of isooctane ca. and $3.0 \mathrm{~mL}$ of saturated sodium chloride were added. The mixture was vigorously stirred for $20 \mathrm{~min}$, and, after phase separation, $1 \mathrm{~mL}$ of the top phase containing fatty acid methyl esters was collected for gas chromatography analysis, using a gas chromatograph (HRGC-3000C Konik Instruments, Barcelona, Spain) equipped with a flame ionization detector and Restek Stabilwax-DA capillary column (30 $\mathrm{m} \times 0.25 \mathrm{~mm}$ i.d., $0.50 \mu \mathrm{m}$ film thickness). The carrier gas was nitrogen with a constant column flow rate of $2.0 \mathrm{~mL} / \mathrm{min}$. The injector temperature was $250^{\circ} \mathrm{C}$ and the detector temperature was $250^{\circ} \mathrm{C}$. The column temperature program was as follows: the initial column temperature was $220^{\circ} \mathrm{C}$, which was maintained for $0.3 \mathrm{~min}$ and then to a final temperature of $240^{\circ} \mathrm{C}$ at a rate of $10^{\circ} \mathrm{C} / \mathrm{min}$ and hold for another $1 \mathrm{~min}$. Fatty acid methyl esters were identified by comparison with retention times and peak areas of the standard fatty acid methyl esters (Sigma, Chemical Co., St. Louis, MO, USA).

The amount of each sample injected was $1.0 \mu \mathrm{L}$. Data were processed by means of specific software (IST-Crom). FA content was calculated as area (g/100 g), measuring the peak area corresponding to each FA and expressing the result as $g$ of FA/100 $\mathrm{g}$ of oil (d.b.).

2.4. Statistical Analysis. The effect of factors (cultivars and planting date) on the fatty acid profile, seed yield, and oil content was evaluated by multifactorial analysis of variance, using the INFOSTAT statistical package [20]. Significant differences among factors were determined at the significance level of $P<0.05$. When this analysis showed statistical differences between factors, the averages were compared through Tukey's test. 


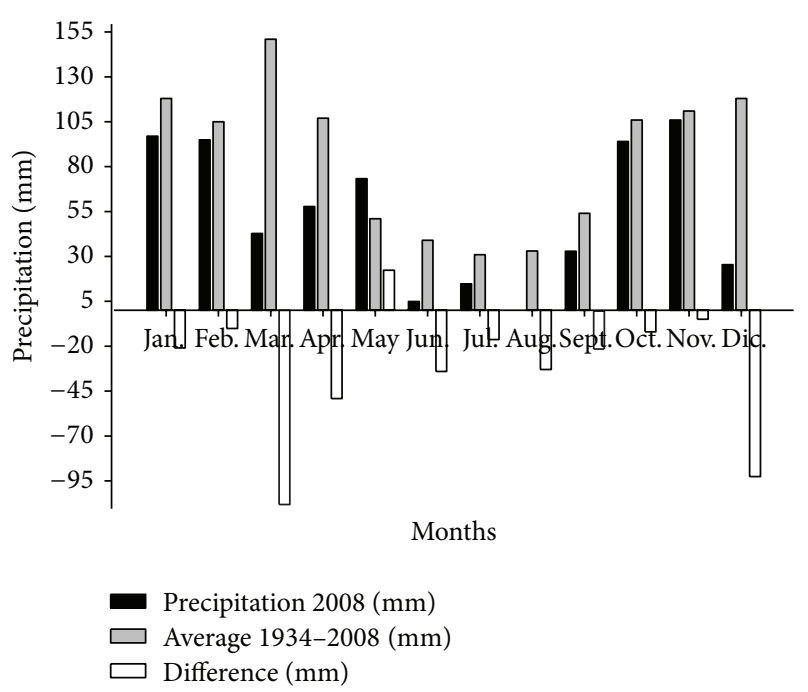

FIGURE 1: Rainfalls recorded during 2008 at Paraná AES and differences with the average in period 1934-2008.

\section{Results and Discussion}

3.1. Climatic Conditions. Figures 1 and 2 show rainfall and temperature conditions during the campaign, which proved to be adequate for temperature.

The average temperature, from flowering to harvest (harvesting dates were November 25, 2008-1st date and December 23, 2008-2nd date), for the first planting date was $20.7^{\circ} \mathrm{C}$, while for late planting date was $23.4^{\circ} \mathrm{C}$.

The accumulated rainfall, during the period from flowering to harvest, for the first planting date, was $135.2 \mathrm{~mm}$, while the second planting date was $132.6 \mathrm{~mm}$. March and April rainfalls, usually characterized by high precipitation, which recharges the soil profile, were $60 \%$ lower than the historical average recorded at INTA-AES Paraná. This fact, together with the scarce rains recorded subsequently until October, resulted in a dry campaign which probably limited the crop yields.

Table 1 shows seed yield $\left(\mathrm{kg} \cdot \mathrm{ha}^{-1}\right)$, oil yield $\left(\mathrm{kg} \cdot \mathrm{ha}^{-1}\right)$, and FA ( $\mathrm{g} / 100 \mathrm{~g})$ profile in the seven analyzed cultivars in the two planting dates.

\subsection{Effect of Cultivar and Planting Date on Oil and Seed Yield.}

Table 2 shows oil and seed yield content $\left(\mathrm{kg} \cdot \mathrm{ha}^{-1}\right)$ of the analyzed cultivars.

A significant effect of cultivars on oil yield was observed $(P: 0.0082)$. The oil yield from Tape INTA cultivar was found to be noticeably lower than that of the rest of cultivars. By contrast, cultivars Baikal, Panambí INTA, Prointa Ceibal, Curundú INTA, Carapé INTA, and Prointa Lucero showed no significant differences among them, with oil yield between $728 \mathrm{~kg} \cdot \mathrm{ha}^{-1}$ and $842 \mathrm{~kg} \cdot \mathrm{ha}^{-1}$.

The delay in planting date also displaces seed filling to periods of high temperature, which affect their oil content and yield.

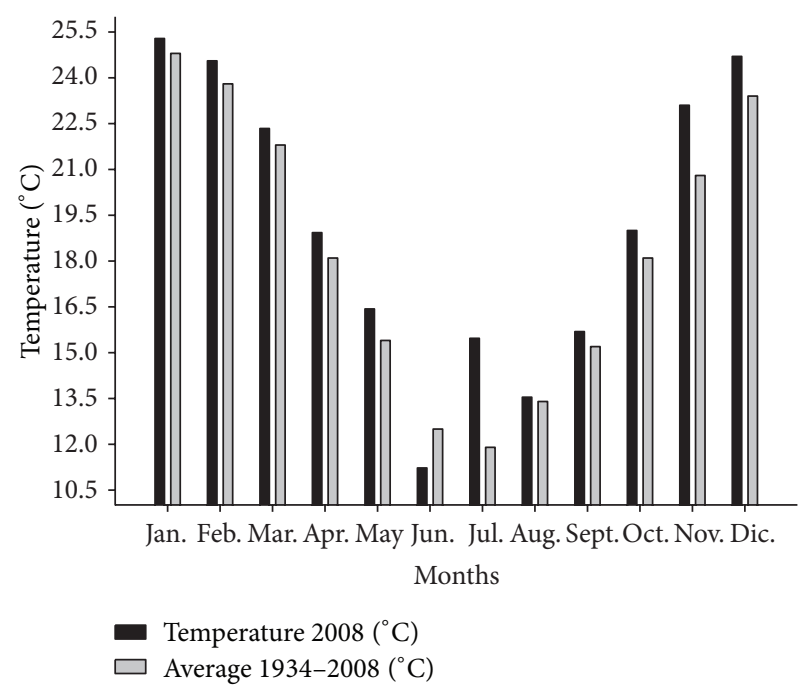

FIgure 2: Temperatures recorded during 2008 at Paraná AES and the average 1934-2008.

In agreement with Lafond et al. [21], oil yield showed a significant response ( $P: 0.0001)$ to planting date, decreasing from $844.75 \mathrm{~kg} \cdot \mathrm{ha}^{-1}$ to $644.35 \mathrm{~kg} \cdot \mathrm{ha}^{-1}$ in the late date (Table 3).

Cultivars showed significant effects for the seed yield variable ( $P$ : 0.0070). Variety Prointa Lucero reached the maximum yield with $1988.89 \mathrm{~kg} \cdot \mathrm{ha}^{-1}$, while Tape INTA presented the lowest yield $\left(1366.78 \mathrm{~kg} \cdot \mathrm{ha}^{-1}\right)$.

The seed yield per hectare obtained in this study was significantly affected by planting date $(P: 0.0001)$. The highest yields were obtained at the early date, with an increase of $434.35 \mathrm{~kg} \cdot \mathrm{ha}^{-1}$. While Lafond et al. [21] did not find effects of planting date on flaxseed yield, other authors [22-25] found that early seeding produces the highest flax yields. The reasons for this behavior could be the same as those mentioned when evaluating the effect on oil yield. Delayed planting date causes the seed fixation and filling period to be located within environmental conditions with higher temperatures, thus resulting in yield reductions.

3.3. Effect of Cultivar and Planting Date on Fatty Acid Profile. Table 4 shows concentration of palmitic, stearic, oleic, linoleic, and linolenic acids, content of saturated and unsaturated FA, and their relationship as a function of the different cultivars.

Concentrations of oleic and linolenic acids showed no significant differences between cultivars $(P: 0.3142$ and $P$ : 0.6522 , resp.), the average for the seven cultivars under study being $30.19 \mathrm{~g} / 100 \mathrm{~g}$ and $47.96 \mathrm{~g} / 100 \mathrm{~g}$, respectively. Cultivars showed to have an effect on palmitic $(P: 0.0060)$, stearic $(P$ : 0.0092), and linoleic ( $P$ : 0.0001$)$ acids.

Palmitic acid occurred in 5-7 g/100 g approximately. Although Tape INTA showed a higher palmitic acid content as compared to the rest, no significant differences were found between this variety and Curundú INTA, Panambí INTA, Carapé INTA, Prointa Ceibal INTA, and Prointa Lucero. 
TABLE 1: Seed yield $\left(\mathrm{kg} \cdot \mathrm{ha}^{-1}\right)$, oil yield $\left(\mathrm{kg} \cdot \mathrm{ha}^{-1}\right)$, and fatty acid profile $(\mathrm{g} / 100 \mathrm{~g})$ in the seven analyzed cultivars in the two planting dates.

\begin{tabular}{|c|c|c|c|c|c|c|c|c|c|c|c|c|}
\hline \multirow{2}{*}{ Cultivars } & \multirow{2}{*}{ PD } & \multirow{2}{*}{ Rep. } & \multirow{2}{*}{ Grain yield } & \multirow{2}{*}{ Oil yield } & \multicolumn{5}{|c|}{ Fatty acid profile } & \multirow{2}{*}{ Sat. } & \multirow{2}{*}{ Unsat. } & \multirow{2}{*}{ Unsat./Sat. } \\
\hline & & & & & $16: 0$ & $18: 0$ & $18: 1$ & $18: 2$ & $18: 3$ & & & \\
\hline \multirow{6}{*}{ Baikal } & \multirow{3}{*}{1} & 1 & 2101 & 927 & 5.7 & 5.8 & 30.0 & 22.0 & 43.7 & 11.5 & 95.7 & 8.3 \\
\hline & & 2 & 1785 & 775 & 5.6 & 5.9 & 29.5 & 19.1 & 47.6 & 11.5 & 96.1 & 8.3 \\
\hline & & 3 & 1933 & 843 & 5.3 & 5.3 & 30.6 & 19.2 & 47.3 & 10.5 & 97.0 & 9.2 \\
\hline & \multirow{3}{*}{2} & 1 & 1431 & 613 & 5.3 & 6.0 & 32.9 & 18.0 & 45.7 & 11.3 & 96.6 & 8.5 \\
\hline & & 2 & 1436 & 611 & 5.7 & 5.4 & 28.7 & 19.5 & 49.0 & 11.2 & 97.2 & 8.7 \\
\hline & & 3 & 1398 & 601 & 5.6 & 5.1 & 30.9 & 18.3 & 45.4 & 10.6 & 94.7 & 8.9 \\
\hline \multirow{6}{*}{ Carapé INTA } & \multirow{3}{*}{1} & 1 & 2313 & 1011 & 6.8 & 7.5 & 29.4 & 17.0 & 46.0 & 14.3 & 92.4 & 6.5 \\
\hline & & 2 & 1986 & 858 & 6.7 & 6.4 & 26.3 & 15.3 & 52.6 & 13.1 & 94.2 & 7.2 \\
\hline & & 3 & 2251 & 975 & 7.0 & 7.6 & 26.4 & 16.6 & 48.3 & 14.6 & 91.2 & 6.2 \\
\hline & \multirow{3}{*}{2} & 1 & 1767 & 760 & 6.9 & 6.8 & 27.1 & 15.8 & 51.1 & 13.7 & 94.0 & 6.9 \\
\hline & & 2 & 1554 & 663 & 6.7 & 7.5 & 28.4 & 15.7 & 47.8 & 14.2 & 91.9 & 6.5 \\
\hline & & 3 & 1680 & 717 & 6.7 & 6.6 & 28.8 & 16.9 & 49.5 & 13.4 & 95.3 & 7.1 \\
\hline \multirow{6}{*}{ Curundú INTA } & \multirow{3}{*}{1} & 1 & 2333 & 1042 & 6.4 & 7.9 & 29.4 & 18.1 & 45.1 & 14.3 & 92.6 & 6.5 \\
\hline & & 2 & 1878 & 833 & 7.5 & 6.6 & 29.9 & 13.4 & 51.4 & 14.1 & 94.7 & 6.7 \\
\hline & & 3 & 1758 & 774 & 6.7 & 7.2 & 25.5 & 19.5 & 48.1 & 13.9 & 93.0 & 6.7 \\
\hline & \multirow{3}{*}{2} & 1 & 1135 & 488 & 6.9 & 9.2 & 31.5 & 16.3 & 44.2 & 16.1 & 92.0 & 5.7 \\
\hline & & 2 & 1429 & 622 & 7.0 & 8.3 & 26.6 & 16.0 & 49.9 & 15.3 & 92.5 & 6.0 \\
\hline & & 3 & 1839 & 799 & 6.9 & 7.6 & 30.0 & 17.1 & 46.0 & 14.5 & 93.0 & 6.4 \\
\hline \multirow{6}{*}{ P. Ceibal } & \multirow{3}{*}{1} & 1 & 2107 & 901 & 7.0 & 13.3 & 22.9 & 14.0 & 49.5 & 20.4 & 86.4 & 4.2 \\
\hline & & 2 & 1570 & 664 & 6.3 & 7.9 & 28.6 & 14.2 & 50.2 & 14.3 & 93.0 & 6.5 \\
\hline & & 3 & 2030 & 856 & 6.3 & 6.7 & 30.4 & 15.7 & 49.1 & 13.0 & 95.1 & 7.3 \\
\hline & \multirow{3}{*}{2} & 1 & 1463 & 611 & 6.6 & 8.0 & 28.0 & 15.5 & 50.1 & 14.6 & 93.5 & 6.4 \\
\hline & & 2 & 1741 & 717 & 6.9 & 8.5 & 28.1 & 14.7 & 48.5 & 15.5 & 91.3 & 5.9 \\
\hline & & 3 & 1651 & 695 & 6.6 & 7.3 & 23.7 & 15.3 & 55.8 & 13.9 & 94.8 & 6.8 \\
\hline & & 1 & 2413 & 1042 & 6.7 & 7.1 & 27.6 & 14.7 & 51.8 & 13.8 & 94.1 & 6.8 \\
\hline & 1 & 2 & 2072 & 878 & 6.3 & 7.6 & 28.7 & 14.7 & 49.8 & 13.9 & 93.2 & 6.7 \\
\hline P. Lucero & & 3 & 1790 & 769 & 6.6 & 6.9 & 30.4 & 15.1 & 49.0 & 13.5 & 94.6 & 7.0 \\
\hline & & 1 & 1659 & 692 & 3.1 & 3.5 & 67.2 & 8.0 & 25.2 & 6.6 & 100.5 & 15.1 \\
\hline & 2 & 2 & 1843 & 767 & 6.5 & 7.7 & 27.5 & 15.2 & 52.6 & 14.1 & 95.3 & 6.8 \\
\hline & & 3 & 2157 & 910 & 6.8 & 8.0 & 31.6 & 14.3 & 47.6 & 14.9 & 93.5 & 6.3 \\
\hline & & 1 & 2154 & 951 & 6.7 & 6.8 & 27.8 & 14.3 & 51.2 & 13.6 & 93.3 & 6.9 \\
\hline & 1 & 2 & 1665 & 733 & 6.7 & 7.6 & 29.5 & 13.5 & 49.3 & 14.3 & 92.4 & 6.5 \\
\hline Panambí & & 3 & 2029 & 886 & 7.2 & 7.6 & 36.1 & 13.2 & 43.1 & 14.8 & 92.4 & 6.2 \\
\hline & & 1 & 927 & 398 & 6.8 & 8.9 & 31.8 & 13.1 & 47.6 & 15.7 & 92.5 & 5.9 \\
\hline & 2 & 2 & 1562 & 675 & 7.0 & 9.9 & 32.9 & 12.4 & 46.4 & 16.9 & 91.8 & 5.4 \\
\hline & & 3 & 1740 & 758 & 6.8 & 7.5 & 30.6 & 13.6 & 49.2 & 14.3 & 93.3 & 6.5 \\
\hline & & 1 & 1932 & 821 & 7.0 & 7.4 & 28.7 & 15.1 & 48.9 & 14.4 & 92.6 & 6.4 \\
\hline & 1 & 2 & 1533 & 647 & 6.5 & 7.2 & 30.5 & 12.7 & 51.0 & 13.7 & 94.2 & 6.9 \\
\hline Tane INTA & & 3 & 1319 & 552 & 6.6 & 7.4 & 29.7 & 15.1 & 49.7 & 14.0 & 94.5 & 6.8 \\
\hline & & 1 & 1198 & 501 & 6.7 & 8.9 & 30.8 & 13.7 & 48.4 & 15.6 & 92.8 & 5.9 \\
\hline & 2 & 2 & 1045 & 436 & 9.4 & 7.5 & 31.5 & 15.7 & 45.7 & 16.9 & 92.9 & 5.5 \\
\hline & & 3 & 1174 & 496 & 6.9 & 8.0 & 31.6 & 14.6 & 46.5 & 14.9 & 92.8 & 6.2 \\
\hline
\end{tabular}


TABLE 2: Oil yield $\left(\mathrm{kg} \cdot \mathrm{ha}^{-1}\right)$ and seed yield $\left(\mathrm{kg} \cdot \mathrm{ha}^{-1}\right)$ of the analyzed cultivars.

\begin{tabular}{lcc}
\hline Cultivars & Oil & Grain yield \\
\hline Baikal & $728.46^{\mathrm{ab}}$ & $1680.53^{\mathrm{ab}}$ \\
Carapé INTA & $830.79^{\mathrm{b}}$ & $1925.18^{\mathrm{b}}$ \\
Curundú INTA & $759.84^{\mathrm{ab}}$ & $1728.71^{\mathrm{ab}}$ \\
P. Ceibal & $740.86^{\mathrm{ab}}$ & $1760.26^{\mathrm{ab}}$ \\
P. Lucero & $842.95^{\mathrm{b}}$ & $1988.89^{\mathrm{b}}$ \\
Panambí INTA & $733.49^{\mathrm{ab}}$ & $1679.44^{\mathrm{ab}}$ \\
Tape INTA & $575.49^{\mathrm{a}}$ & $1366.78^{\mathrm{a}}$ \\
\hline
\end{tabular}

${ }^{*}$ Different letters in the same column indicate significant difference according to Tukey's test $(P<0.05)$ between cultivars.

TABLE 3: Average among the oil yield $\left(\mathrm{kg} \cdot \mathrm{ha}^{-1}\right)$ and seed yield $\left(\mathrm{kg} \cdot \mathrm{ha}^{-1}\right)$ at two planting dates.

\begin{tabular}{lcc}
\hline Planting date & Oil yield & Seed yield \\
\hline PD1 & 844.75 & 1950.00 \\
PD2 & 644.35 & 1515.65 \\
\hline
\end{tabular}

PD1: June 11, 2008.

PD2: July 30, 2008.

The least percentage corresponded to Baikal, though with no significant difference with Prointa Lucero, Prointa Ceibal, and Carapé INTA.

Stearic acid concentration was statistically different among the cultivars under study. Cultivar Prointa Ceibal was found to have the highest one, followed by Panambí INTA, Curundú INTA, Tape INTA, Carapé INTA, Prointa Lucero, and Baikal with the least content.

Linoleic acid concentration occurred within 13.35 and $19.34 \mathrm{~g} / 100 \mathrm{~g}$, Baikal showing $6 \mathrm{~g} / 100 \mathrm{~g}$ higher content than Panambí INTA. The remaining cultivars presented amounts between both figures.

The content obtained for FA was as follows: palmitic acid: 6 g/100 g; stearic acid: 4.4 g/100 g; oleic acid: 24.2 g/100 g; linoleic acid: $15.3 \mathrm{~g} / 100 \mathrm{~g}$; and linolenic acid: $50.1 \mathrm{~g} / 100 \mathrm{~g}$ [25] obtained similar values for palmitic acid (6-7 g/100 g), stearic acid (3-5 g/100 g), and linoleic acid (13-15 g/100 g), lower for oleic acid (16-20 g/100 g) and higher for linolenic acid (50$56 \mathrm{~g} / 100 \mathrm{~g})$. The differences found in these contents may be due to different environmental conditions.

Regarding FA, significant differences were found between saturated and unsaturated ones among cultivars but were not found between the saturated/unsaturated ratio $(P: 0.026 ; P$ : 0.0089; P: 0.0209, resp.).

The highest content of saturated FA was found in Prointa Ceibal $(15.27 \mathrm{~g} / 100 \mathrm{~g})$ and the least in Baikal cultivar $(11.11 \mathrm{~g} / 100 \mathrm{~g})$, the rest having intermediate values.

Unsaturated FA, on the other hand, showed Prointa Ceibal as the cultivar with the least content $(92.36 \mathrm{~g} / 100 \mathrm{~g})$ and Baikal with the highest $(96.20 \mathrm{~g} / 100 \mathrm{~g})$, with a difference of $3.84 \mathrm{~g} / 100 \mathrm{~g}$ between them.

The extreme values for both saturated and unsaturated FA differ from those reported by [26] and [27] since our results exceed them in almost $3 \mathrm{~g} / 100 \mathrm{~g}$ and $5 \mathrm{~g} / 100 \mathrm{~g}$ for saturated and unsaturated, respectively.

References [26] and [27] found that the amount of total unsaturated fatty acids in flax cultivar was $87-91 \mathrm{~g} / 100 \mathrm{~g}$, whereas for total saturated fatty acids were 9-12 g/100 g.

The average for the seven cultivars under study was 6.94.

Average for seven cultivars of palmitic, stearic, oleic, linoleic, and linolenic acids, content of saturated and unsaturated FA, and unsaturated/saturated ratio, at two planting dates, is shown in Table 4.

FA composition, saturated and unsaturated content, and saturated/unsaturated ratio were not statistically affected by planting dates.

Although not significant, data showed that late planting date, associated with higher daily temperatures, increased the oleic acid content from $28.95 \mathrm{~g} / 100 \mathrm{~g}$ to $31.43 \mathrm{~g} / 100 \mathrm{~g}$ in the second planting date and decreased linolenic acid from $48.68 \mathrm{~g} / 100 \mathrm{~g}$ to $47.24 \mathrm{~g} / 100 \mathrm{~g}$. The decrease in the linolenic acid could be attributed to the fact that its accumulation ceases at $30^{\circ} \mathrm{C}[28]$.

Considering flax for use as functional food in the early date, Prointa Lucero had the highest content of linolenic acid while in the late date Prointa Ceibal had the highest content.

Although no significant effects of planting date were found on linolenic acid during this campaign, a marked effect had been in fact reported by [19] in three planting dates (June 1, 12 July, and 4 August). Probably, a later planting date had been optimal for their effect on the content of linolenic acid (Table 5).

3.4. Interactions between the Studied Factors. When considering the results, the interaction cultivar versus planting date was not significant in none of the five FA under studies, as well as on the saturated and unsaturated FA, the saturated/unsaturated ratio, oil content, and seed yield.

\section{Conclusions}

Regarding the FA profile, significant differences were found between cultivars for palmitic, stearic, and linoleic acids content. The planting dates did not significantly affect palmitic, stearic, oleic, linoleic, and linolenic acids. However, results suggest that the flowering to maturity period adopted in this study was not the most appropriate; that is, temperatures recorded during such period did not favor seed formation and oil accumulation and the planting date subsequent to the second half of July reduced significantly the seed and oil yields.

No cultivar versus planting date interaction was observed in fatty acid composition, content of saturated and unsaturated FA, and saturated/unsaturated ratio, oil content, and seed yield.

Taking into account the effects of different planting dates on linolenic acid, it can be concluded that Prointa Lucero variety should be used when planting at an early date, whereas Ceibal INTA should be considered if planting at late dates. In this way, the highest content of linolenic acid could be obtained, and flaxseed could be used as functional food. 
TABLE 4: Average concentration of palmitic, stearic, oleic, linoleic, and linolenic acids, and content of saturated, unsaturated (g/100 g), and unsaturated/saturated ratio in the analyzed cultivars in the two planting dates.

\begin{tabular}{lcccccccc}
\hline Cultivars & Palmitic & Stearic & Oleic & Linoleic & Linolenic & Sat. & Unsat. & Unsat./Sat \\
\hline Baikal & $5.53^{\mathrm{a}}$ & $5.58^{\mathrm{a}}$ & $30.43^{\mathrm{a}}$ & $19.34^{\mathrm{c}}$ & $46.43^{\mathrm{a}}$ & $11.11^{\mathrm{a}}$ & $96.20^{\mathrm{b}}$ & $8.67^{\mathrm{a}}$ \\
Carapé INTA & $6.80^{\mathrm{ab}}$ & $7.08^{\mathrm{ab}}$ & $27.73^{\mathrm{a}}$ & $16.23^{\mathrm{ab}}$ & $49.19^{\mathrm{a}}$ & $13.87^{\mathrm{ab}}$ & $93.16^{\mathrm{ab}}$ & $6.73^{\mathrm{a}}$ \\
Curundú INTA & $6.91^{\mathrm{b}}$ & $7.81^{\mathrm{ab}}$ & $28.80^{\mathrm{a}}$ & $16.71^{\mathrm{bc}}$ & $47.44^{\mathrm{a}}$ & $14.71^{\mathrm{b}}$ & $92.96^{\mathrm{ab}}$ & $6.33^{\mathrm{a}}$ \\
P. Ceibal & $6.64^{\mathrm{ab}}$ & $8.63^{\mathrm{b}}$ & $26.95^{\mathrm{a}}$ & $14.89^{\mathrm{ab}}$ & $50.52^{\mathrm{a}}$ & $15.27^{\mathrm{b}}$ & $92.36^{\mathrm{a}}$ & $6.20^{\mathrm{a}}$ \\
P. Lucero & $6.00^{\mathrm{ab}}$ & $6.81^{\mathrm{ab}}$ & $35.50^{\mathrm{a}}$ & $13.67^{\mathrm{a}}$ & $46.00^{\mathrm{a}}$ & $12.81^{\mathrm{ab}}$ & $95.18^{\mathrm{ab}}$ & $8.11^{\mathrm{a}}$ \\
Panambí INTA & $6.87^{\mathrm{b}}$ & $8.05^{\mathrm{b}}$ & $31.47^{\mathrm{a}}$ & $13.35^{\mathrm{a}}$ & $47.80^{\mathrm{a}}$ & $14.92^{\mathrm{b}}$ & $92.62^{\mathrm{a}}$ & $6.24^{\mathrm{a}}$ \\
Tape INTA & $7.19^{\mathrm{b}}$ & $7.72^{\mathrm{ab}}$ & $30.47^{\mathrm{a}}$ & $14.47^{\mathrm{ab}}$ & $48.34^{\mathrm{a}}$ & $14.91^{\mathrm{b}}$ & $93.29^{\mathrm{ab}}$ & $6.29^{\mathrm{a}}$ \\
\hline
\end{tabular}

${ }^{*}$ Different letters in the same column indicate significant difference according to Tukey's test $(P<0.05)$ between cultivars.

TABLE 5: Average among the seven cultivars of palmitic, stearic, oleic, linoleic, and linolenic acids, content of saturated and unsaturated fatty acids (g/100 g), and unsaturated/saturated ratio at two planting dates.

\begin{tabular}{lcccccccc}
\hline Planting date & Palmitic & Stearic & Oleic & Linoleic & Linolenic & Sat. & Unsat. & Unsat./Sat. \\
\hline PD1 & 6.55 & 7.33 & 28.95 & 15.82 & 48.68 & 13.88 & 93.45 & 6.85 \\
PD2 & 6.57 & 7.44 & 31.43 & 15.23 & 47.24 & 14.01 & 93.90 & 7.03 \\
\hline
\end{tabular}

PD1: June 11, 2008.

PD2: July 30, 2008.

\section{Abbreviations}

FA:

Fatty acids

PUFA: Polyunsatured fatty acid

Linolenic acid: $18: 3 n-3$

Linoleic acid: $18: 2 \mathrm{n}-6$

d.b.: $\quad$ Dry basis.

\section{Conflict of Interests}

The authors declare that there is no conflict of interests regarding the publication of this paper.

\section{Acknowledgments}

This research was funded by INTA Paraná Agricultural Experimental Station (Argentina). The publication of this paper has been made possible by technical support from the Food Technology Institute, College of Chemical Engineering, Universidad Nacional del Litoral (Argentina).

\section{References}

[1] B. D. Oomah, "Flaxseed as a functional food source," Journal of the Science of Food and Agriculture, vol. 81, no. 9, pp. 889-894, 2001.

[2] P. P. Acosta, Enciclopedia Argentina de Agricultura y Jardinería, Lino para Semilla y Fibra. Ed. ACME S.A.C.I. Bs As., 1980.

[3] O. Çopur, M. A. Gür, M. Karakus, and U. Demirel, "Determination of corr elation and path analysis among yield components and seed yields in oil flax varieties (Linum usitatissimum L.)," Journal of Biological Sciences, vol. 6, no. 4, pp. 738-743, 2006.

[4] M. Enser, R. I. Richardson, J. D. Wood, B. P. Gill, and P. R. Sheard, "Feeding linseed to increase the n-3 PUFA of pork: fatty acid composition of muscle, adipose tissue, liver and sausages," Meat Science, vol. 55, no. 2, pp. 201-212, 2000.
[5] M. Kouba, M. Enser, F. M. Whittington, G. R. Nute, and J. D. Wood, "Effect of a high-linolenic acid diet on lipogenic enzyme activities, fatty acid composition, and meat quality in the growing pig," Journal of Animal Science, vol. 81, no. 8, pp. 1967-1979, 2003.

[6] M. Kouba, "Effect of dietary omega-3 fatty acids on meat quality of pigs and poultry," in Omega 3 Fatty Acid Research, M. C. Teale, Ed., pp. 225-239, Nova, New York, NY, USA, 2006.

[7] Flax Council of Canada. Nutrition, 2013, http://www.flaxcouncil.ca/english/index.jsp? $\mathrm{p}=\mathrm{g} 4 \& \mathrm{mp}=$ nutrition .

[8] H. Yoshida, S. Kanrei, Y. Tomiyama, and Y. Mizushina, "Regional characterization of tocopherols and distribution of fatty acids within soybean seeds (Glycine max L.)," Journal of Food Lipids, vol. 13, no. 1, pp. 12-26, 2006.

[9] N. Salem Jr., A. P. Simopoulos, C. Galli, M. Lagarde, and H. R. Knapp, "Fatty acids and lipids from cell biology to human disease," Lipids, vol. 31, p. S1, 1996.

[10] A. P. Simopoulos, "Omega-3 fatty acids in health and disease and in growth and development," The American Journal of Clinical Nutrition, vol. 54, no. 3, pp. 438-463, 1991.

[11] D. Ansorena and I. Astiasarán, “The use of linseed oil improves nutritional quality of the lipid fraction of dry-fermented sausages," Food Chemistry, vol. 87, no. 1, pp. 69-74, 2004.

[12] J. D. Wood, R. I. Richardson, G. R. Nute et al., "Effects of fatty acids on meat quality: a review," Meat Science, vol. 66, no. 1, pp. 21-32, 2004.

[13] F. H. Lehberg, W. G. McGregor, and W. F. Geddes, "Flax studies. IV. The physical and chemical characteristics of flaxseed at progressive stages of maturity," The Canadian Journal of Research, vol. 17, no. 6, pp. 181-194, 1939.

[14] R. Casa, G. Russell, B. Lo Cascio, and F. Rossini, "Environmental effects on linseed (Linum usitatissimum L.) yield and growth of flax at different stand densities," European Journal of Agronomy, vol. 11, no. 3-4, pp. 267-278, 1999.

[15] W. Adugna and M. T. Labuschagne, "Association of linseed characters and its variability in different environments," Journal of Agricultural Science, vol. 140, no. 3, pp. 285-296, 2003. 
[16] C. D. Dybing, P. D. Evenson, and C. Lay, "Relationships among daily flower production, length of the flowering period, and seed yield of flax," Crop Science, vol. 28, no. 2, pp. 287-292, 1988.

[17] C. D. Dybing and D. C. Zimmerman, "Temperature effects on flax (Linum usitatissimum L.) growth, seed production, and oil quality in controlled environments," Crop Science, vol. 5, no. 2, pp. 184-187, 1965.

[18] J. A. Robertson and W. H. Morrison, "Analysis of oil content of sunflower seed by wide-line NMR," Journal of the American Oil Chemists' Society, vol. 56, no. 12, pp. 961-964, 1979.

[19] C. D. Bannon, G. J. Breen, and J. D. Craske, "Analysis of fatty acid methyl esters with high accuracy and reliability. III. Literature review of and investigations into the development of rapid procedures for the methoxide-catalysed methanolysis of fats and oils," Journal of Chromatography, vol. 247, no. 1, pp. 71-89, 1982.

[20] J. A. Di Rienzo, F. Casanoves, M. G. Balzarini, L. Gonzalez, M. Tablada, and C. W. Robledo, InfoStat Versión, Grupo InfoStat, FCA, Universidad Nacional de Córdoba, Brujas, Argentina, 2010.

[21] G. P. Lafond, B. Irvine, A. M. Johnston et al., "Impact of agronomic factors on seed yield formation and quality in flax," Canadian Journal of Plant Science, vol. 88, no. 3, pp. 485-500, 2008.

[22] L. C. Burnett, "Sowing date in relation to stands and yields of flax," in Proceedings of the Flax Institute of the United States, Minneapolis, Minn, USA, 1942.

[23] S. C. Sheppard and T. E. Bates, "Probability of response of flax to nitrogen fertilizer dependent upon planting date and weather," Canadian Journal of Soil Science, vol. 68, no. 2, pp. 271-286, 1988.

[24] C. R. Thompson, B. K. Hoag, and J. R. Lukach, "Flax variety response to planting date," North Dakota Farm Research, vol. 45, pp. 22-26, 1988.

[25] H. J. Choi, S. Y. Park, and S. K. Kim, "Effect of seeding time on fatty acid composition, oil contents and seeds yield in flax," Korean Journal of Plant Resources, vol. 5, no. 6, pp. 700-706, 2012.

[26] R. Bhatty, "Nutrient composition of whole flaxseed and flaxseed meal," in Flaxseed in Human Nutrition, S. C. Cunnane and L. U. Thompson, Eds., pp. 22-42, AOCS Press, Champaign, Ill, USA, 1995.

[27] W.-S. Choo, J. Birch, and J.-P. Dufour, "Physicochemical and quality characteristics of cold-pressed flaxseed oils," Journal of Food Composition and Analysis, vol. 20, no. 3-4, pp. 202-211, 2007.

[28] C. D. Dybing and D. C. Zimmerman, "Fatty acids accumulation in maturing flaxseeds as influenced by environment," Plant Physiology, vol. 41, no. 9, pp. 1465-1470, 1966. 


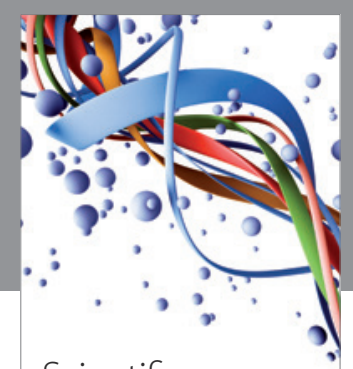

Scientifica
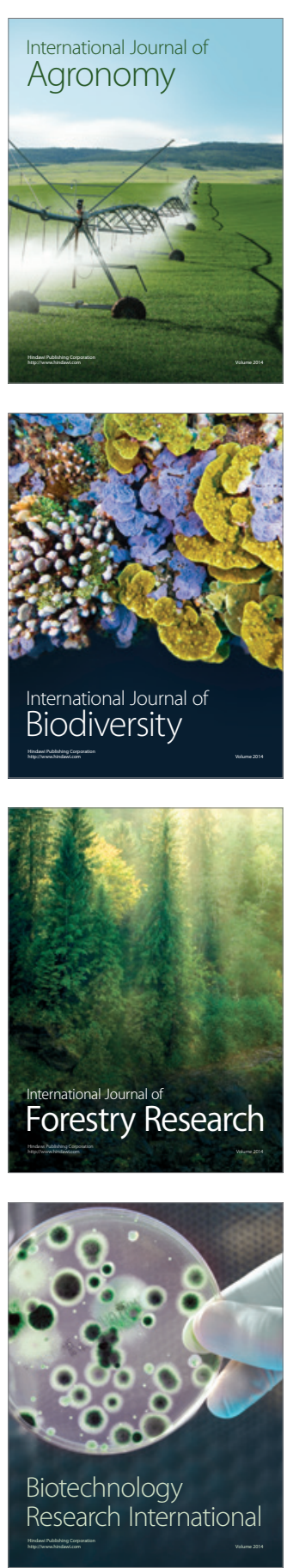
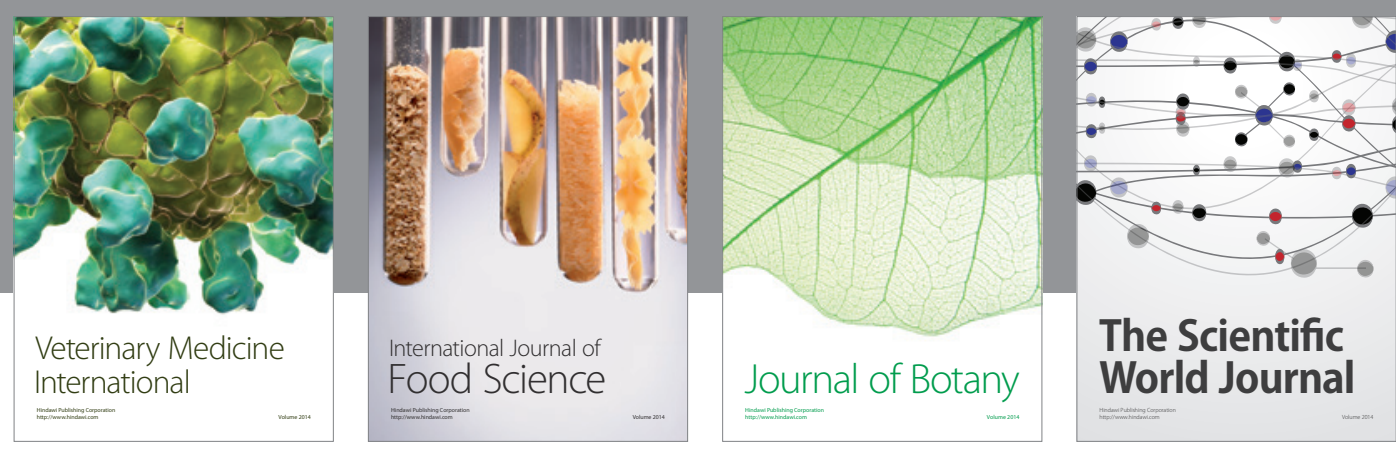

The Scientific World Journal
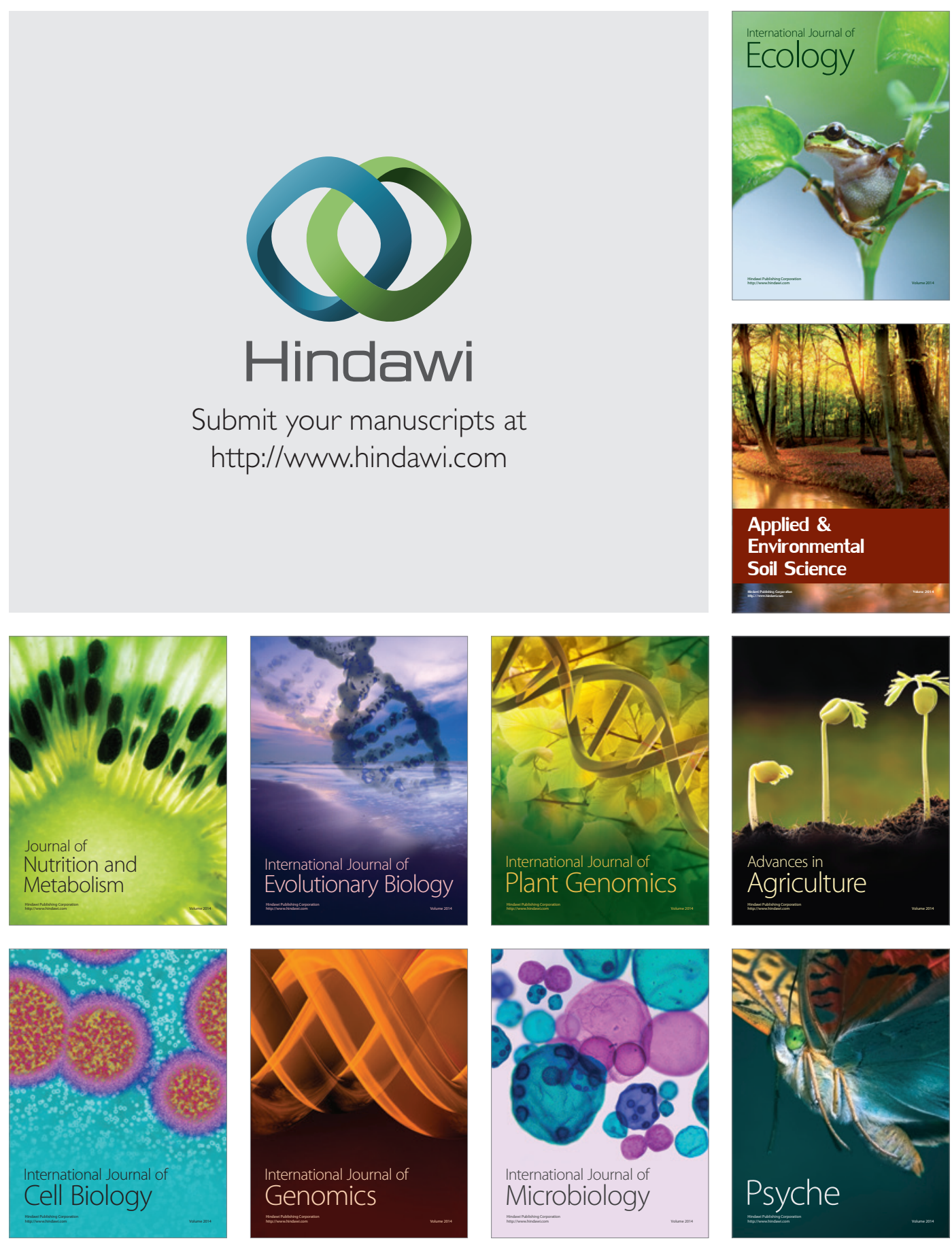